\title{
SOCIAL VALUATION OF CITY PUBLIC RESIDENTIAL SPACE
}

\author{
Lidia Groeger, PhD \\ Chair of Spatial Development and Spatial Planning \\ Lodz University \\ e-mail: groeger@interia.pl
}

\begin{abstract}
The paper presents the attributes of good public residential space within cities. Features of public residential space significant for city inhabitants at the place of residence were defined. Valuation of the desired qualities of public residential space at the place of residence and valuation of the existing qualities of public residential space at the current place of residence were determined according to surveys conducted among 1,500 inhabitants in 6 cities. The level of maladjustment of qualities of public residential space and the expectations of inhabitants were defined according to the obtained indicators.
\end{abstract}

Keywords: public residential space, city, valuation of space.

JEL Classification: R21, R23, R28, R29, H41, H42.

Citation: Groeger L., (2013), "Social valuation of city public residential space", Real Estate Management and Valuation, vol. 21, no. 2, pp. 56-63.

DOI: $10.2478 /$ remav-2013-0017.

\section{Introduction}

Public space is the main component of the urban space structure, its physiognomy, organization and development, including the social factor; creating and using it generates the quality of public space in which we function and consider attractive. Public spaces are created by city users, therefore, looking at them from the viewpoint of existing and future users, it is very important to take into consideration the current cultural and socio-economic development of city inhabitants. As a result of their varied character (symbolic, functional, consumer) and importance (public spaces: metropolitan, urban, local) there is no single model of good public space that can be considered universal and generally accepted (JAŚKIEWICZ 2001).

Public space on the local scale, localized in the area of housing developments and related to the basic dwelling function, plays a major role in the life of inhabitants. Such space enables social interaction, facilitates the development of bonds between neighbors and provides a sense of satisfaction and safety ( WALLIS 1990, STRUMIŁŁO 2010, BONENBERG 2008, BAĆ 2004).

Quality public space promotes the given area and contributes to its further development. It has significant impact on property values. Well developed and organized public space can be used by everyone, not just the residents, but also district authorities and developers that will invest in attractive locations (MARKOWSKI 2001).

Since the ' 90 s, investors have been paying extra attention to public residential spaces functioning in the free-market environment, as their proximity constitutes a value added to other urban real-estate (CAMPBELl 1976, GROEGER 2011). The nearness of a well-developed pond, park and other city greens increases the value of neighboring properties (CROMPTON 2005, MIERZEJEWSKA 2001, GROEGER 2011, CZOCHAŃSKI 2009). The ideas of people dealing with real-estate appraisal and management can deviate from actual appraisals and declared preferences of residents (KARWIŃSKA 2008). Up-to-date information received from city residents concerning what qualities of public residential space are 
significant for them and how expected they are at the current place of residence can be used rationally in property management and appraisal process.

\section{Public residential space}

According to the Act on spatial planning and development dated March 27th 2003, public space is to be understood as an "area of significant importance for satisfying the needs of residents, improving their quality of life and contributing to establishing social relations due to its location and functionalspatial qualities, determined in the study of determinants and spatial development directions of the district".

Such a specific understanding of the term "public space”, limited only to public spaces as found in spatial development plans, narrows the set of possible types of space actually perceived as public by the residents. This is why in this study, public space is understood according to the definition assumed during the $3^{\text {rd }}$ Congress of Polish Urban Planning of the Association of Polish Cities and Society of Polish Town Planners (BIEGAŃSKI et al. 2009), which stresses the particular value of public spaces as a common commodity in the sustainable development of urban space. Public space is defined in social and economic aspects. It is understood as a "common functional commodity, purposefully shaped by people according to social values and principles - serving the purpose of satisfying the needs of local and pan-local communities. Public character of specific space is decided by its collective use" (BIEGAŃSKI et al. 2009).

Public space is created by the community in the process of use, observation, attribution of appropriate importance and valorization, as described by Jałowiecki in his paper on the social creation of space (JAŁOWIECKI 1988). Such space constitutes a value for individuals and groups using it. People attribute value to it, depending on their knowledge, experience, cultural models or intuitive perception of reality (MAJER 2010). The form and function of public space depends on the social system of values and existing conditions, as well as on the quality and effectiveness of law enforcement, local authorities and public institutions (KARP et al. 2009).

Public residential space is a commodity that does not only have specific functional features, but constitutes a place of the transmission of different material and immaterial products satisfying different needs. Because of this it constitutes a commodity and resource of strategic importance for local communities and requires particular attention in respect to the rational planning thereof. The „Public Space Charter" published after the $3^{\text {rd }}$ Congress of Polish Urban Planning of the Association of Polish Cities and Society of Polish Town Planners in 2009, specifies threats to the correct approach to the shaping of public space, including the understanding of public space with a dominant residential function. At the time, the following have been highlighted (BIEGAŃSKI et al. 2009):

1) a low public awareness of a commodity common to the state and its citizens, due to the lack of a tradition of respecting the common good,

2) the false opinion that the free market, without public intervention, is capable of balancing spatial and socio-economic development,

3) prioritizing individual interests over the common good, especially in respect to spatial planning and development,

4) insufficient participation of the community in taking decisions related to spatial and socioeconomic development.

\section{Features of good public residential space}

References to publications describing features of well-functioning public spaces indicate leading ideas for assessing their proper functioning. According to Gehl, public space must create the right environment to perform three types of activities (GEHL 2009):

- basic - related to the completion of ongoing needs, such as commuting to work or waiting for transport, on which the quality of the space has little impact,

- optional - mainly different forms of leisure and recreation, on which the quality of the space has significant impact,

- social - resulting from the previous two, existing where interaction between people is possible.

ALEXANDER (2008) pointed out that "Social pathologies associated with urban life inevitably result from lack of close contacts". To establish such close contacts "people concerned must see each other 
frequently, almost daily", therefore, people need friendly public space that they will want to use in their daily existence.

KOCHANOWSKI (2002) and ZUZIAK (2002) recognized general accessibility for public use as an attribute of good public space, irrespective of the form of ownership. CHMIELEWSKI (2001), on the other hand, pointed not only to general accessibility, but also to the anonymity of users and safety, including freedom from threats and arduousness, the legibility of the system facilitating spatial awareness, as well as high aesthetic, symbolic and informative qualities which are attractive to the public.

Another attribute of good public space should be its nodal character that fuses the residential substance, service centers, shops, transport and communication routes, and cultural and educational centers. Such a 'connector' should be aesthetically attractive, so that the stay in a public space will be pleasant for the residents and additionally increase the prestige of a given location. Such space must be neat and tidy, as well as appropriately scaled to its form of use (SCHNEIDER-SKALSKA 2007).

As features of good public space, Szczepański included urban and architectural order with cohesive spatial composition, functional order related to living comfort, aesthetic order defining the appearance of given space and social order related to the social ties and social identification with the given location. The sum assessment of all these orders determines the valuation of a given space. As the idea of order can be perceived subjectively, different individual features of residents resulting from their age, education, wealth or cultural features determine the value a given public space (JAEOWIECKI, SZCZEPAŃSKI 2006).

On the other hand, ZAEĘCKI (2003) expanded attributes of good public space outside of the residents' perspective. He pointed out the importance of a technical infrastructure, including waterworks and a sewage system, as well as the condition of roads, sidewalks, parking places and street illumination. He also attributed high importance to properly maintained and developed greens. These observations were confirmed by Groeger's research carried out in Łódź on a group of clients of real-estate brokers (2004).

\section{Valuation ${ }^{1}$ of desired features of public residential space by city residents}

To determine the features of public residential space important to city inhabitants, the present study has been preceded by a survey containing open questions concerning features which are important to city inhabitants at their place of residence. The initial survey was carried out in Pabianice, Ozorków and Łódź on a group of 300 respondents.

The actual survey covered 1,500 residents of 6 cities, representing different types of urban residential space (Łódź, Bełchatów, Stryków, Główno, Łask, and Rzgów) (GROEGER 2013). The survey was carried out between 2010 and 2012. Quantum selection was utilized, so that each type of residential space was represented by the same number of respondents (250 surveys from each city). The purpose of such a selection was to determine the valuation of elements of urban residential space development by city residents, taking into consideration the diversification resulting from the heterogeneous state of urban residential space. The selected cities representing individual types of urban residential space include small towns - Stryków, Rzgów, small cities -Łask, Głowno, larger cities - Bełchatów, and big cities, such as Łódź. A fixed number of respondents from each of the analyzed cities were selected, taking into consideration the gender and age structure of the city inhabitants. In the case of larger cities, such as Łódź and Bełchatów, the respondents' place of residence was taken into consideration upon their selection so that the entire city was covered by the survey. Such an

\footnotetext{
1 The dictionary of socio-economic geography terms defines the valuation of a person's environment from the viewpoint of his or her needs. "A person will satisfy his needs (food, health, residence etc.) through using the resources of his environment. Assessment of the environment is related to the choice of locations in the space, where the needs of this person are optimally satisfied ( $\rightarrow$ map of preferences). Valuation of the environment can also apply to the emotional bond with the environment (satisfaction, indifference, feeling of safety or threat, dissatisfaction). Valuation of the environment is related to individual aspirations, strives and preferences resulting from the value system they believe in. Therefore the values are the subject of research of $\rightarrow$ social geography, as they remain in a cause-and-effect relation with the behavior of people in the given space. Researching the values accepted by people, we discover the perception of the world, the scale of importance of events occurring in this world and orientation of activities," (RUNGE, RUNGE 2008).
} 
approach to the selection of respondents assured the valuation of all types of residential space by the residents of all types of urban residential space, not just the most frequently studied and selected inhabitants of large cities, i.e., clients of construction industry fairs and exhibitions or people intending to purchase a flat on the primary market. The wide spectrum of city inhabitants, good and very good knowledge of the city on the level from approx. 60\% (Eódź) to approx. 80\% in smaller cities (Rzgów, Stryków) as declared by the respondents, and the selection applied for quantum samples of respondents creates a basis for drawing conclusions regarding the current valuation of residential space by city inhabitants.

Respondents from 6 cities within the Lodz Voivodeship were asked to evaluate the features of public residential space. Fifteen features recognized as desirable at the place of residence were evaluated. Respondents evaluated the features twice. The first evaluation applied to the importance they place on the quality of given features at the preferred place of residence. In the case of the second evaluation, the respondents assessed their current place of residence from the viewpoint of the 15 distinguished features. The results of this survey were two sets of data defining the importance of desirable public residential space features according to city residents. The comparison of these assessments allowed the author to define the distance between people's preferences and their assessment of the current place of residence.

A scale of 0 - 5, 0 indicating no importance, 1 - very low importance, 2 - low importance, 3 average importance, 4 - high importance and 5 - very high importance was used to valuate the significant features of public residential space at the preferred place of residence. The assessments revealed a range of results, between 1 and 5 points. The average values of points awarded by the respondents show that the desired features of public residential space were evaluated at anywhere from 3.5 (accessibility to a church) to 4.52 (safety at place of residence).
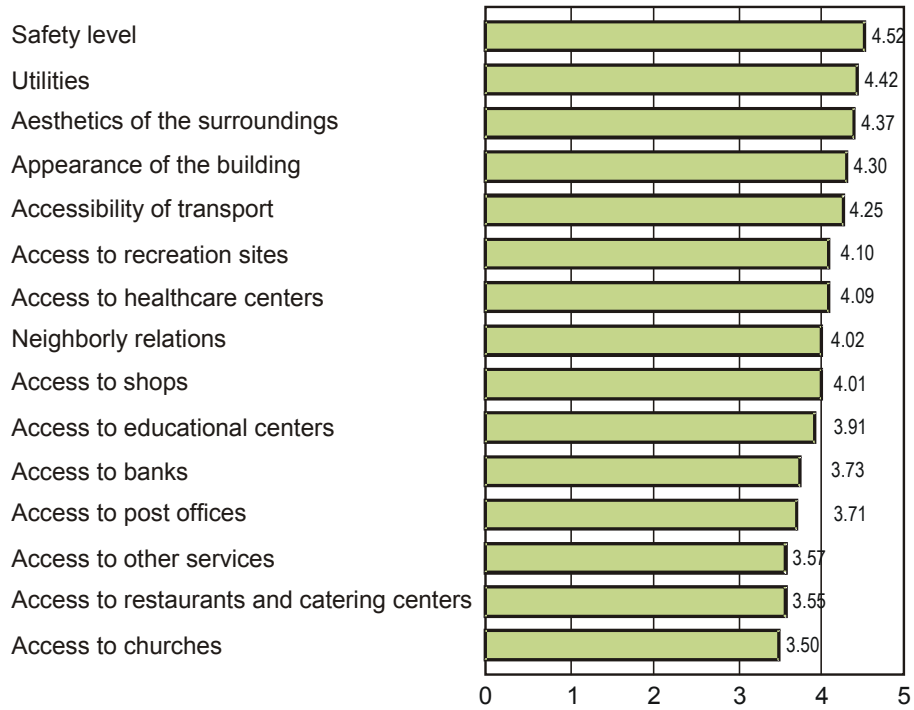

Fig. 1. Valuation of desired features of public residential space by city inhabitants. Source: own research according to surveys carried out in Łódź, Bełchatów, Łask, Głowno, Stryków, Rzgów on 1,500 respondents between 2010 and 2012.

Utilities, aesthetics of the surroundings, appearance of the building, accessibility of transport, neighborly relations and access to recreation sites, healthcare centers, and shops were found to be the most valued features of public residential space. All these features were assessed at over 4 points, i.e., as important at the place of residence. One could observe the following regularity: the higher a feature was rated the smaller the variation in its scores. The respondents showed the highest concordance in respect to valuation of the feeling of safety and aesthetics of the surroundings. In these cases, the variation coefficient did not exceed $16 \%$, which indicates a very small variability of the scores.

Accessibility to churches, restaurants and catering centers, post offices and banks was valued the lowest. Although the respondents acknowledged the need for such facilities at their place of residence, other features of public residential space were considered more important. The importance of the former was valued between 3.5 and 3.7 points. At the same time, the assessment of the lowest-rated 
features was most differentiated and reached $34 \%$, which indicates a moderate variation of scores. One should point out that the accessibility to different service providers and centers was scored medium to low against the other scores, with the exception of healthcare centers.

Another step of the research was to define the assessment of public residential space at the respondents' current place of residence. In the case of this analysis, the highest scores were attributed to utilities (4.2), neighborly relations (3.86) and the accessibility to churches (3.85) (Figure 2).

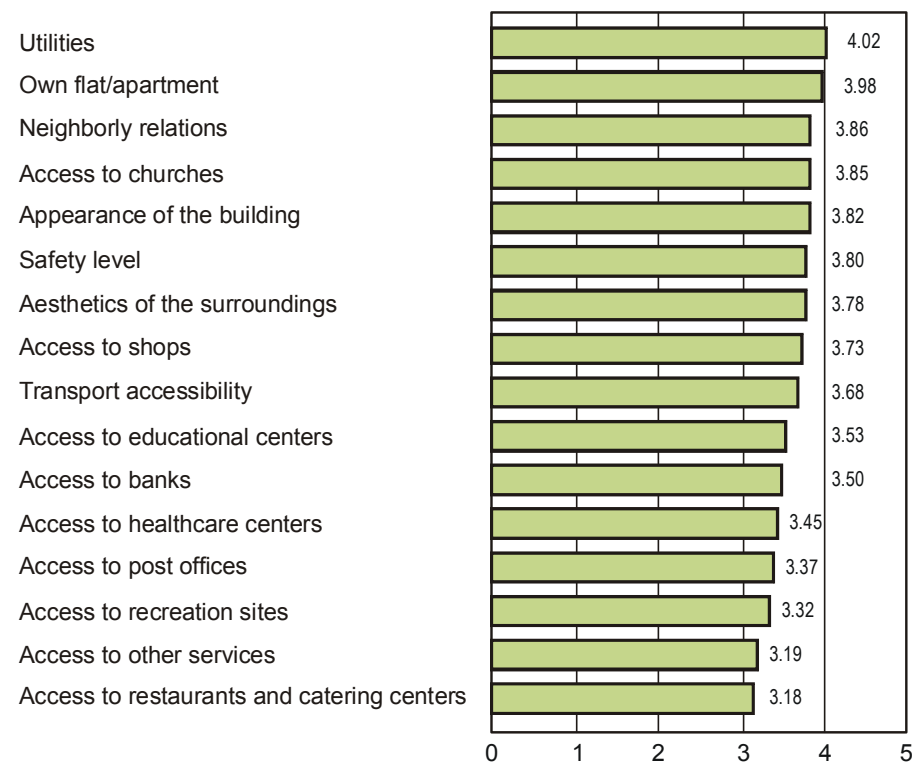

Fig. 2. Valuation of public residential space at the inhabitants' current place of residence of. Source: own research according to surveys carried out in Łódź, Bełchatów, Łask, Głowno, Stryków, Rzgów

Another group of coinciding scores included transport accessibility, safety level, aesthetics of the surroundings and access to shops, whereas access to restaurants and catering centers, access to other services, recreation sites, post offices and healthcare centers at the current space of residence were given the lowest values. In general, most scores fluctuated between 3.18 and 3.86. At the same time, the variation in the scores of public residential space at the current place of residence was found to be higher than in the case of scores recorded in the valuation of the significance of public residential space features important to the quality of the place of residence. The variation of scores (as measured by the variation coefficient) was most often $3 \%$ higher. This shows that reality is valuated in a slightly more diversified way than people's opinions regarding the importance of particular public residential space features. Variation coefficients ranged from $18 \%$ to $31 \%$, which indicates a moderate diversification of scores.

\section{Level of maladjustment between current and preferred place of residence}

Valuations concerning the preferred public residential space and evaluation of the current place of residence in terms of public residential space features become more transparent if we take into consideration the differences between the scores. The applied valuation method enables such comparisons. From the cognitive aspect, such information shows what features of public residential space are most maladjusted to the needs of city inhabitants, or as shown in our study, when reality exceeds their expectations. The differences show how maladjusted the level of public residential space features in individual cities is, and can be a valuable source of information in indicating what investments in public residential space are desired by the city inhabitants.

Proposing a simple indicator showing the disparity between the desired and actual valuation of public residential space simplifies the analysis of maladjustment between the current and preferred place of residence. The difference between the Wp and Wr for individual features in each city enables the most desired actions in respect to the surveyed features of public residential space to be determined

Average maladjustment coefficient (distance) $=\sum$ (desired feature value coefficient - coefficient of this feature at the current place of residence) / number of features taken into account. 


$$
\hat{\mathrm{W}}=\sum(\mathrm{Wp}-\mathrm{Wr}) / \mathrm{N}
$$

$\hat{\mathrm{W}} \quad$ - average maladjustment factor,

$\mathrm{Wp}$ - average coefficient of the value of features preferred by the inhabitants of a given city,

$\mathrm{Wr} \quad$ - average coefficient of the value of features at the inhabitants' current place of residence in a given city,

$\mathrm{N}$ - number of features accounted for by the survey.

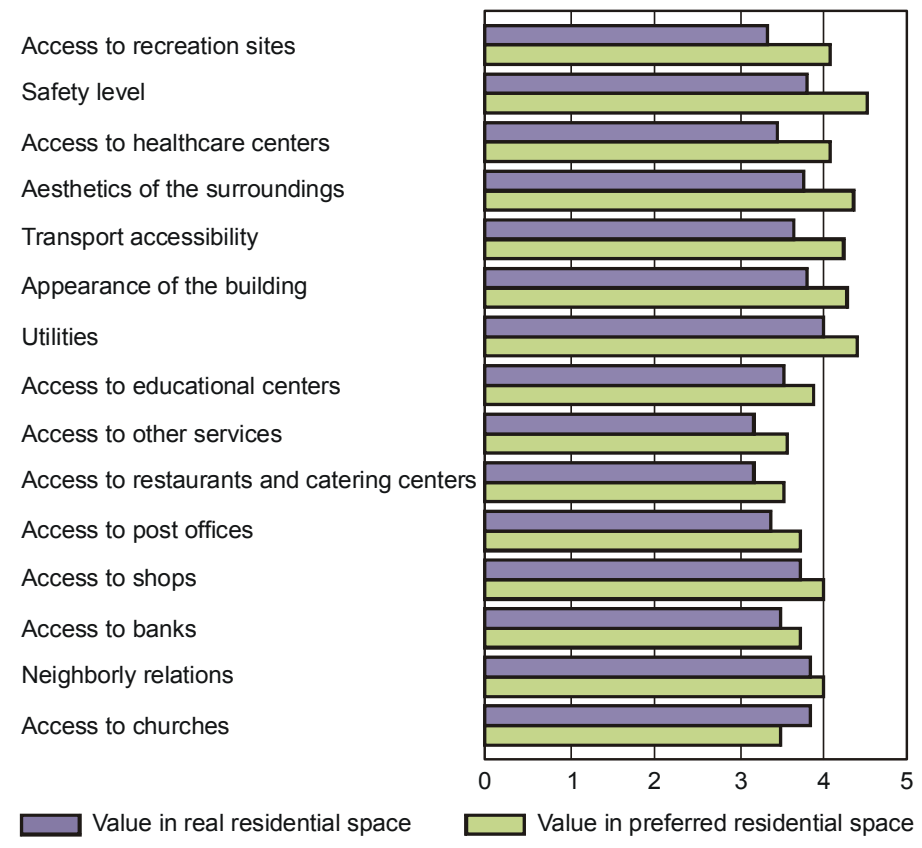

Fig. 3. The average level of valuation of public residential space features at the current place of residence and desired level of public residential space valuation as indicated by the surveyed 1,500 city inhabitants. Source: own research according to surveys carried out in Łódź, Bełchatów, Łask, Głowno, Stryków, Rzgów between 2010 and 2012.

In the group of 15 researched features of public residential space in 6 cities representing diversified types of urban residential space, the span of differences in expectations and valuation of the actual place of residence ranged from 0.35 (accessibility to churches) to 0.78 (accessibility to recreational sites).

The values were positive for all factors except for the accessibility to churches, which indicates that the development of this feature in public residential space requires further research. The fact that one coefficient was characterized by a negative score tells us that the actual status of this feature exceeds expectations. This atypical situation applies to the accessibility to churches where the coefficient had a negative value in all cities. However, in Łask, Bełchatów and Łódź, it reached a score as low as - 0.5, which may be due the excessive number of churches in the public residential space of these cities that makes new investments in this area not justified.

The greatest deficiencies observed by city inhabitants concerned access to recreational sites. Coefficients describing this feature were the highest amongst all maladjustment factors. The worst situation in the case of this aspect concerned the city of Stryków, where the maladjustment factor reached 1.04 and was the highest amongst all coefficients of analyzed features of public residential space in the 6 surveyed cities. Bearing in mind that, due to its unique location, the Stryków district reports one of the highest incomes per inhabitant in Poland, it has funds to attend to recreation sites for its inhabitants; this makes the fact that such strongly expressed needs of inhabitants are not fulfilled even more surprising.

Another feature with a very high maladjustment coefficient was the safety level, scoring 0.72 . The lowest scores in this respect were recorded for Łódź (0.96) and Łask (0.81), whereas inhabitants of Rzgów had the greatest comfort in this topic (0.59). 
High maladjustment factors were recorded for access to healthcare centers (0.64). Rzgów, Stryków and Głowno scored the poorest here. In addition to the above, transport accessibility also scored high, with Stryków obtaining the poorest scores in this area. This shows that the inhabitants do not feel any benefits from the nearby intersection of two expressways, and even see their place of residence as isolated in terms of transport accessibility. Inhabitants of Łódź and Łask gave this feature the highest scores. The remaining maladjustment factors ranged between 0.16 (neighborly ties) and 0.4 (utilities).

Among the surveyed cities, Bełchatów scored the best in respect to the adaptation of public residential space to the needs of its inhabitants, with the average maladjustment factor reaching only 0.25 , mainly due to the high scores recorded for public residential space in the current place of residence.

Łódź, the capital of the voivodeship, placed second, which indicates a relatively high satisfaction of its inhabitants with public residential space in comparison to the declared significance thereof. However, the situation in Łódź is specific, as the inhabitants of this city declared the lowest significance of public residential space features at the place of residence and, at the same time, gave the lowest scores to the actual status of the city in this respect. This is why the maladjustment factor was low and why the analysis of its level separately from its components could distort the actual picture of public residential space valuation for this city. The truth of the matter is that if city authorities wish to increase public residential space value in the opinion of its inhabitants, they should concentrate on increasing the safety, aesthetics of the surroundings and accessibility to recreational sites.

\section{Summary}

If one was to attempt to generally indicate what needs related to public residential space are least satisfied, safety would place first, followed by aesthetics of the surroundings, transport accessibility, recreation sites and access to healthcare centers. This is the basic set of unsatisfied needs regarding public residential space according to current city inhabitants. A relatively low need related to the location of churches, shops and other services can suggest that these needs do not have to be satisfied at the analyzed places of residence.

Accessibility to recreation sites, such as parks and other green areas, and the need to feel safe in public spaces at the given place of residence is the strongest and, irrespective to the represented residential space, these questions are always raised by the inhabitants as they perceive them as the greatest discomfort.

The results of the present study provide a picture of the specific variances between people's expectations and their actual perception of current public residential space. They give objective information on the subjective valuation of public residential space by city inhabitants. Weights attributed to the individual features indicate the importance of a given element to city inhabitants. The obtained results reveal the following regularities:

According to the inhabitants, the smaller the city the more important the features of public residential space generally are.

In general, the inhabitants of small cities attribute a higher value to public space at their current place of residence. However, compared to the opinions of inhabitants of other cities, one could not help but notice that needs related to the access to healthcare centers at the place of residence and the ability to use recreation sites had not been satisfied.

In all cities, the access to churches at the current place of residence was valued higher than when the preferred features were concerned. This shows that city inhabitants consider the access to churches at their place of residence greater than expected. This atypical situation, applicable to only one feature, shows that, at the moment, there is no need for new churches in the public residential space of cities.

The lowest values attributed to public residential space features at the current place of residence were noted in Łódź. What is more, the same applied to the valuation of public residential space features desired by inhabitants of this city.

A question remains as to why the inhabitants of Łódź attribute much lower weight to features of public residential space than people living in smaller cities. Could it be that shopping and entertainment centers like "Manufaktura" are taking over the functions of public residential space and that places of residence have become nothing more than mere "sleeping quarters"? 


\section{Bibliography}

AleXANDer C., 2008, Język wzorców, Gdańskie Wydawnictwo Psychologiczne, Kraków.

BIEGAŃSKI L., BucZeK G., GZell S., KOWALEWSKI A., MARKOWSKI T., CichY-PAZDER E., 2009, Karta Przestrzeni Publicznej. [W:] CichY-PAZDER E., MARKOwSKI T. (RED.), Nowa urbanistyka - nowa jakość życia, „biblioteka Urbanisty".

BONENBERG W., 2008, Przestrzeń publiczna w osiedlach mieszkaniowych, [w:] „Urbanista” 12.

CAMPBell A., 1976, The Quality of American life: perceptions, evaluations and satis-faction, Russel Sage FOUNDATION, NEW YORK.

CASTELS M., 1982, Kwestia miejska, PWN WARSZAWA.

CHMIELEWSKI J., 2001, Teoria urbanistyki $w$ projektowaniu $i$ planowaniu miast, Wyd. Politechniki Warszawskiej, Warszawa.

CROMPTON, JL. , 2005, The impact of parks on property values: empirical evidence from the United States, Managing Leisure, 10(4), 203-218.

CZOCHAŃSKI J., 2010, Zachowanie i ksztattowanie terenów zielonych na obszarze wielkich miast, jako stymulantów rozwoju i jakości życia, (W) LORENS P., MARTYNIUK-PĘCZAK J.(RED.), Wybrane zagadnienia przestrzeni publicznej, Urbanista.

GEHL J., 2009, Życie między budynkami. Użytkowanie przestrzeni publicznych, Wyd. RAM.

GROEGER L.2002, Zagospodarowanie przestrzenne a wartość nieruchomości mieszkaniowych ( na przykładzie Łodzi), (w) Badania Naukowe, Wyższa Szkoła Umiejętności w Kielcach, Zeszyt 4, Kielce.

Groeger L., 2004, Waloryzacja przestrzeni mieszkaniowej (w opiniach klientów tódzkich biur obrotu nieruchomościami), Wydawnictwo UŁ, Łódź.

Groeger L. 2011, Przestrzeń publiczna generatorem atrakcyjności przestrzeni mieszkaniowej osiedli mieszkaniowych, [W] JAŻDŻEWSKA I., XXIV Konwersatorium Wiedzy o Mieście.

GROEGER L.,2013, Zróżnicowanie $i$ wartościowanie przestrzeni mieszkaniowej na przykładzie miast województwa tódzkiego, (praca przygotowywana do druku).

JAŁOWIECKI B., 1988, Społeczne wytwarzanie przestrzeni, Książka i Wiedza, Warszawa.

JAŁOWIECKI B., SZCZEPAŃSKI M., 2006, Miasto i przestrzeń $w$ perspektywie socjologicznej, Scholar, Warszawa.

JAŚKIEWICZ M., 2001, Wielkomiejskie przestrzenie publiczne, (W) MARKOWSKI T.(RED.)Rozwój regionalny i przestrzeń publiczna. Biuletyn KPZK PAN, Warszawa, z. 194.

KARP J., TERTELIS M., SIMON V., 2009, Zarządzanie wartościa nieruchomości mieszkaniowych, C.H. Beck, Warszawa.

KARWIŃSKA A., 2008, Gospodarka przestrzenna. Uwarunkowania społeczno-kulturowe, Wyd. Naukowe PWN, Warszawa.

KochanOWSKI J., 2002, Przestrzeń publiczna miasta postindustrialnego, Wyd. Politechniki Gdańskiej.

MAJER A., 2010, Socjologia i przestrzeń miejska, Wyd. Naukowe PWN, Warszawa.

MARKOWSKI T., 2001, Przestrzeń publiczna w ekonomice rozwoju miast, w: Rozwój regionalny i przestrzeń publiczna, Biuletyn, KPZK PAN, Warszawa, z.194.

MiERZEJEWSKA L., 2001, Tereny zielone w strukturze przestrzennej Poznania, PTPN, Poznań.

Psychologia organizacji przestrzeni środowiska mieszkaniowego, 2004, BAĆ Z. (RED.) Habitaty 2003, Oficyna Wydawnicza Politechniki Wrocławskiej, Wrocław.

RUNGE A., RUNGE J., 2008, Stownik pojęć z geografii społeczno-ekonomicznej, Wyd. Videograf, Katowice.

SCHNEIDER-SKALSKA, 2007, Kształtowanie zdrowego środowiska mieszkaniowego. Wybrane zagadnienia, Politechnika Krakowska, Kraków.

STRUMIŁŁO K., 2010, Luksus, na jaki każdy sobie zastużyt - mieszkać w nowoczesnym i pięknym otoczeniu na miarę XXI wieku., Architecturae et Artibus 2010 Vol.2 nr 2 s.69-72.

WALLIS A., 1990, Socjologia przestrzeni, Warszawa.

ZAŁĘCKI J., 2003, Przestrzeń społeczna Gdańska w świadomości jego mieszkańców, Wydawnictwo Naukowe Uniwersytetu Gdańskiego, Gdańsk.

ZuZIAK Z.K., 2002, Nowe przestrzenie podróży. Przestrzenie publiczne węzów transportu, [w]: KochanowsKi. M. (red.) Przestrzeń publiczna miasta postindustrialnego, Wyd. Politechniki Gdańskiej. 